\title{
Pengaruh pola tanam tumpangsari jagung dan kedelai terhadap pertumbuhan dan hasil jagung hibrida dan evaluasi tumpangsari di Arjasari Kabupaten Bandung
}

\section{Effect of maize hybrid-soybean intercropping on growth and yield of maize hybrid in Arjasari Bandung}

\author{
Diterima : 11 Desember 2017/Disetujui : 18 Desember 2017 / Dipublikasikan : 30 Desember 2017
}

CDepartment of Crop Science, Padjadjaran University

\begin{abstract}
Maize and soybean are important food after paddy in Indonesia. Maize and soybean consumption increase continually due to population growth. One of the ways to increase crop production can be done by intercropping. Intercropping is a planting system by growing two or more crops simultaneously on the same land in one year. The objectives of this research were to determine appropriate maize hybrid genotype and soybean combinations in intercropping system. The experiment was carried out from March 2016 to August 2016 at Arjasari, Bandung Regency with altitude about $960 \mathrm{~m}$ above the sea level. The experimental design was used in this study was Randomized Block Design (RBD) which consisted of twenty treatments and two replications. The treatment was eighteen genotypes and two check genotypes which consisted of F1B X 4.8.8, F1E X 1.1.3, F1D X 3.1.4, F1F X G203, F1A X 4.8.8, F1E X 3.1.4, F1H X G-673, F1I X G203, F1B X 1.1.3, F1E X 3.1.4, F1C X G203-1, F1G X 16.5.15, F1D X 16.5.15, F1H X 1.1.3, F1A X 16.5.15, F1I X G673, F1G X 673, F1C X 4.8.8, Maros $1 \times 2$ and Maros 11 × 12. Each genotype intercropped with soybean plants. The result showed that the treatment of intercropping maize and soybean could affect the growth and the production of maize genotypes F1F x 3.1.4, Maros $1 \times 2$, and Maros $11 \times 12$. The treatment of maize hybrid genotypes F1B x 1.1.3, F1B x 4.8.8, F1I $x$ G203-1, Maros $1 \times 2$ and Maros $11 \times 12$ intercropped with soybean gave the best effect on the dry seed grain weight per plot reaching 2,60 $3,30 \mathrm{~kg} \cdot \mathrm{m}^{-2}$ equal to5,77 - 7,34 ton.ha-1.
\end{abstract}

Keywords: hybrid maize, soybean,intercropping

\begin{tabular}{l}
\hline Dikomunikasikan oleh Tien Turmuktini \\
\hline Yuwariah $\mathrm{Y}^{1} \cdot$ D. Ruswandi ${ }^{1}$ A.W. Irwan \\
\\
1)Staff Departemen Budidaya Pertanian Universitas \\
Padjadjaran \\
Korespondensi : yuyun.yuwariah@unpad.ac.id
\end{tabular}

Sari Jagung dan kedelai merupakan tanaman pangan terpenting setelah padi di Indonesia. Konsumsi jagung dan kedelai akan terus mengalami peningkatan setiap tahun dikarenakan pertambahan jumlah penduduk. Salah satu upaya untuk meningkatkan produksi tanaman dapat dilakukan dengan cara tumpangsari. Sistem tumpangsari merupakan sistem pertanaman dengan menanam dua atau lebih jenis tanaman secara serentak pada lahan yang sama dalam waktu satu tahun. Penelitian bertujuan untuk mengetahui genotip jagung hibrida yang terbaik ditumpangsarikan dengan kedelai. Percobaan dilaksanakan dari bulan Maret 2016 sampai bulan Agustus 2016 di Arjasari, Kabupaten Bandung dengan ketinggian tempat mencapai $960 \mathrm{~m}$ di atas permukaan laut. Rancangan yang digunakan dalam penelitian ini adalah Rancangan Acak Kelompok (RAK) yang terdiri dari 20 perlakuan dan diulang sebanyak 2 kali, dengan perlakuan 18 genotip jagung hibrida dan 2 genotip jagung pembanding (kontrol), terdiri dari F1B X 4.8.8, F1E X 1.1.3, F1D X 3.1.4, F1F X G203, F1A X 4.8.8, F1E X 3.1.4, F1H X G-673, F1I X G203, F1B X 1.1.3, F1E $X$ 3.1.4, F1C X G203-1, F1G X 16.5.15, F1D X 16.5.15, F1H X 1.1.3, F1A X 16.5.15, F1I X G673, F1G X 673, F1C X 4.8.8, Maros 1 x 2 dan Maros $11 \times 12$ yang masing-masing ditumpang-sarikan dengan tanaman kedelai varietas. Hasil percobaan menunjukkan bahwa sistem tanam tumpangsari jagung dan kedelai berpengaruh yang lebih baik terhadap pertumbuhan dan hasil tanaman jagung genotip hibrida dibandingkan genotip pembanding/ kontrol F1F x 3.1.4, Maros $1 \times 2$, dan Maros $11 \times 12$. Perlakuan jagung hibrida genotip F1B x 1.1.3, F1B x 4.8.8, F1C $x$ 4.8.8, F1I x G203-1, Maros 1 x 2 dan Maros 11 x 12 yang ditumpangsarikan dengan kedelai memberikan pengaruh terbaik terhadap bobot 
biji pipilan kering per petak sebesar 2,60 - 3,30 kg.m ${ }^{-2}$ setara dengan $5,77-7,34$ ton.ha- ${ }^{-1}$

Kata kunci : jagung hibrida, kedelai, tumpangsari

\section{Pendahuluan}

Jagung (Zea mays L.) merupakan salah satu tanaman pangan yang digunakan sebagai makanan pokok kedua setelah padi di Indonesia. Suarni dan Yasin (2011) memaparkan bahwa jagung merupakan sumber protein yang penting bagi masyarakat. Jagung mengandung serat pangan yang dibutuhkan tubuh seperti asam lemak esensial, isoflavon, mineral $(\mathrm{Ca}, \mathrm{Mg}, \mathrm{K}$, $\mathrm{Na}, \mathrm{P}, \mathrm{Ca}$ dan $\mathrm{Fe}$ ), antosianin, betakaroten, komposisi asam amino esensial, dan lainnya. Pada tahun 2016, pemerintah memutuskan untuk mengimpor jagung sebanyak 2,4 juta ton sebagai pakan ternak. Kebutuhan jagung nasional terus meningkat mencapai 8,6 juta ton per tahun atau sekitar 665 ribu ton/bulan (Kemenperin, 2016). Menurut BPS 2016 bahwa pada tahun 2011-2015, laju pertumbuhan luas areal panen jagung mengalami fluktuatif, sedangkan untuk rata-rata produksi jagung di Indonesia pada tahun 2011-2015 sebesar 49,69 $\mathrm{ku} / \mathrm{ha}$.

Tanaman penting selain jagung yaitu kedelai. Kedelai merupakan tanaman polongpolongan terpenting pertama di Indonesia dan tanaman pangan ketiga terpenting setelah padi dan jagung di Indonesia. Tanaman kedelai berasal dari dataran China. Kedelai mulai dibudidayakan di Indonesia sejak tahun 1746 (Sumarno, 2011). Kedelai merupakan salah satu tanaman pangan sumber protein nabati. Kedelai sebagai salah satu sumber protein nabati menjadi pilihan yang lebih terjangkau dibandingkan protein hewani.

Target produksi kedelai nasional pada tahun 2016 sebesar 2,63 juta ton (Litbang, 2016). Pusat Data dan Sistem Informasi Pertanian (2015) menyatakan bahwa pada tahun 2016 pasokan kedelai akan mengalami defisit sebesar 1,61 juta ton. Konsumsi kedelai akan terus mengalami peningkatan setiap tahunnya dikarenakan bertambahnya populasi penduduk, kesadaran masyarakat akan konsumsi makanan bergizi, dan peningkatan pendapatan per kapita (Aldillah, 2015).
Usaha yang dapat dilakukan untuk meningkatkan produksi tanaman dapat dilaku-kan dengan cara ekstensifikasi, intensifikasi, dan diversifikasi tanaman per tahun atau tanam ganda (Yuwariah, 2011). Hasil tanaman jagung dapat ditingkatkan dengan penggunaan benih yang berkualitas, sehingga diperlukan varietas unggul. Penggunaan benih jagung hibrida merupakan salah satu langkah untuk meningkatkan hasil tanaman jagung dari segi produktivitas, resisten terhadap hama penyakit, responsif terhadap unsur hara tertentu, memiliki daya tumbuh yang baik.

Salah satu upaya tanam ganda untuk meningkatkan produksi yaitu melalui tumpangsari. Tumpangsari adalah sistem pertanaman dua jenis atau lebih tanaman secara serempak pada lahan yang sama dalam waktu satu tahun (Beets, 1982). Sistem tanam tumpangsari serealia dengan legum yang biasa digunakan petani tidak selalu memberikan hasil yang baik dikarenakan pemilihan varietas yang tidak sesuai (Belel et al., 2014).

Keuntungan penerapan sistem tumpangsari dapat dilihat dari Nisbah Kesetaraan Lahan (NKL). Nilai kesetaraan lahan lebih dari 1, menunjukkan keuntungan (Yuwariah, 2011). Penelitian yang dilakukan di China menunjukkan bahwa tumpangsari jagung dengan kedelai memberikan hasil Nisbah Kesetaraan Lahan sebesar 1.14 (Lv et al., 2014).

Genotip jagung hibrida yang digunakan pada penelitian merupakan jagung hibrida hasil persilangan three way cross yang menggunakan tetua-tetua dari Laboratorium Pemuliaan Tanaman Universitas Padjadjaran. Penelitian Syafii dkk (2015) menunjukkan bahwa tetua-tetua yang digunakan memiliki nilai variablitas yang cukup tinggi pada sistem tanam dengan sengon sehingga dapat dijadikan sebagai bahan dasar pengembangan genotip jagung tahan naungan.

Apabila jagung hibrida sebagai tanaman utama ditumpangsarikan dengan kedelai untuk optimalisasi produktivitas lahan, maka diperlukan penggunaan genotip jagung hibrida yang memiliki respons terbaik serta penggunaan kedelai yang tahan naungan terhadap pertumbuhan dan hasilnya. Maka dari itu diperlukan adanya penelitian tumpangsari berbagai genotip jagung hibrida dengan kedelai.

Penelitian ini dilakukan dengan maksud mengetahui pengaruh tumpangsari jagung hibrida dengan kedelai terhadap pertumbuhan 
dan hasil jagung hibrida, sedangkan tujuannya adalah untuk mengetahui genotip jagung hibrida yang paling baik ditumpangsarikan dengan kedelai. Hasil penelitian ini diharapkan mampu memberikan informasi tentang pertumbuhan dan hasil terbaik pada genotip jagung hibrida dalam sistem tumpangsari jagung hibrida dengan kedelai.

\section{Bahan dan Metode}

Percobaan ini dilakukan pada bulan Maret sampai Agustus 2016 di kebun Sanggar Penelitian, Latihan dan Pengembangan Pertanian (SPLPP) Fakultas Pertanian Universitas Padjadjaran Unit Arjasari, Kecamatan Arjasari, Kabupaten Bandung.

Bahan yang digunakan dalam penelitian ini adalah benih Jagung Hibrida sebanyak 18 genotip dan 2 genotip cek/Kontrol/pembanding, terdiri dari F1B X 4.8.8, F1E X 1.1.3, F1D X 3.1.4, F1F X G203, F1A X 4.8.8, F1E X 3.1.4, F1H X G-673, F1I X G203, F1B X 1.1.3, F1E X 3.1.4, F1C X G203-1, F1G X 16.5.15, F1D X 16.5.15, F1H X 1.1.3, F1A X 16.5.15, F1I X G673, F1G X 673, F1C X 4.8.8, genotip pembanding Maros $1 \times 2$ dan Maros $11 \times 12$. Benih Kedelai varietas Agromulyo, Furadan 3G, Decis, Dithane, pupuk kandang, pupuk majemuk NPK (15:15:15)

Metode yang digunakan pada percobaan adalah metode eksperimen Rancang Acak Kelompok (RAK), terdiri dari 20 perlakuan tumpangsari sistem baris antara jagung dan kedelai diulang dua kali. Persiapan lahan dilakukan dengan cara tanah diolah pada satu minggu sebelum tanam. Luas masing-masing petak perlakuan- adalah $3 \times 1,5 \mathrm{~m}$ sebanyak 40 petak untuk tumpangsari jagung hibrida dengan kedelai, 20 petak untuk jagung hibrida tumpangsari, dan 1 petak untuk kedelai tunggal.

\section{Hasil dan Pembahasan}

Hasil Kedelai Varietas Agromulyo. Pada Tabel 1, terlihat bahwa hasil kedelai (datanya tidak dianalisis secara statistik), tanaman kedelai saja/kedelai tunggal yaitu 508,8 g/petak ${ }^{-1}(1,13$ ton $/$ ha $\left.^{-1}\right)$, sedangkan hasil tanam tumpangsari jagung dan kedelai, yaitu berkisar 101,45-158,40 g. petak ${ }^{-1}\left(0,23-0,35\right.$ ton ha $\left.^{-1}\right)$, Berdasarkan deskripsi tanaman kedelai varietas Agromulyo, adalah 1,5-2,0 $\mathrm{t} / \mathrm{ha}^{-1}$. Rendahnya hasil kedelai ini dimungkinkan karena persaingan dengan jagung dalam hal tempat tumbuh dan cahaya.

Tabel 1. Tumpangsari Jagung dan Kedelai Terhadap Hasil Kedelai.

\begin{tabular}{|c|c|c|}
\hline $\begin{array}{c}\text { Perlakuan } \\
\text { Tumpangsari jagung + } \\
\text { kedelai }\end{array}$ & $\begin{array}{l}\text { Bobot Biji } \\
\text { Kering per } \\
\text { Petak (g) }\end{array}$ & $\begin{array}{l}\text { Bobot Biji } \\
\text { Kering per } \\
\text { Hektar } \\
\text { (ton) }\end{array}$ \\
\hline $\mathrm{A}=\mathrm{F} 1 \mathrm{~A} \times 16.5 .15+$ kedelai & 113,32 & 0,25 \\
\hline $\mathrm{B}=\mathrm{F} 1 \mathrm{~A} \times 4.8 .8+$ kedelai & 108,30 & 0,24 \\
\hline $\mathrm{C}=\mathrm{F} 1 \mathrm{~B} \times 1.1 .3+$ kedelai & 101,45 & 0,23 \\
\hline $\mathrm{D}=\mathrm{F} 1 \mathrm{~B} \times 4.8 .8+$ kedelai & 158,40 & 0,35 \\
\hline $\mathrm{E}=\mathrm{F} 1 \mathrm{C} \times 4.8 .8+$ kedelai & 148,05 & 0,33 \\
\hline $\mathrm{F}=\mathrm{F} 1 \mathrm{C} \times \mathrm{G} 203-1+$ kedelai & 154,10 & 0,34 \\
\hline$G=F 1 D \times 16.5 .15+$ kedelai & 136,40 & 0,30 \\
\hline $\mathrm{H}=\mathrm{F} 1 \mathrm{D} \times 3.1 .4+$ kedelai & 136,70 & 0,30 \\
\hline $\mathrm{I}=\mathrm{F} 1 \mathrm{E} \times 1.1 .3+$ kedelai & 123,55 & 0,27 \\
\hline $\mathrm{J}=\mathrm{F} 1 \mathrm{E} \times 3.1 .4+$ kedelai & 133,80 & 0,30 \\
\hline $\mathrm{K}=\mathrm{F} 1 \mathrm{~F} \times 3.1 .4+$ kedelai & 138,30 & 0,31 \\
\hline $\mathrm{L}=\mathrm{F} 1 \mathrm{~F} \times \mathrm{G} 203-1+$ kedelai & 113,05 & 0,25 \\
\hline $\mathrm{M}=\mathrm{F} 1 \mathrm{G} \times 16.5 .15+$ kedelai & 130,45 & 0,29 \\
\hline $\mathrm{N}=\mathrm{F} 1 \mathrm{G} \times \mathrm{G}-673+$ kedelai & 107,90 & 0,24 \\
\hline $\mathrm{O}=\mathrm{F} 1 \mathrm{H} \times 1.1 .3+$ kedelai & 136,40 & 0,30 \\
\hline $\mathrm{P}=\mathrm{F} 1 \mathrm{H} \times \mathrm{G}-673+$ kedelai & 123,90 & 0,28 \\
\hline $\mathrm{Q}=\mathrm{F} 1 \mathrm{I}$ x G203-1 + kedelai & 126,80 & 0,28 \\
\hline $\mathrm{R}=\mathrm{F} 1 \mathrm{I} \times \mathrm{G} 673$ + kedelai & 122,20 & 0,27 \\
\hline$S=$ Maros $1 \times 2+$ kedelai & 124,50 & 0,28 \\
\hline $\mathrm{T}=$ Maros $11 \times 12+$ kedelai & 134,70 & 0,30 \\
\hline
\end{tabular}

\section{Pertumbuhan Tanaman jagung}

Tinggi Tanaman. Berdasarkan Tabel 2, menunjukkan semua perlakuan genotip jagung hibrida berbeda tidak nyata dibanding genotip yang sudah dilepas hal ini karena tidak adanya persaingan dalam mendapatkan cahaya matahari antara tanaman jagung dan kedelai.

Tinggi tanaman jagung pada 8 MST berkisar dari 170,63 hingga 247,75 $\mathrm{cm}$ hal ini sesuai didukng oleh Salvagiotti et al., (2008), bahwa tanaman kedelai dapat menambat nitrogen dari udara, sehingga kebutuhan nitrogen untuk tanaman jagung dapat terpenuhi.

Indeks Luas Daun. Berdasarkan Tabel 3 bahwa, tumpangsari jagung dan kedelai berbeda tidak nyata dibanding dengan kontrol. Gardner (1991), menyatakan bahwa intensitas cahaya matahari berpengaruh terhadap nilai ILD berbeda-beda bergantung pada tinggi tanaman dan jumlah sinar matahari yang diterima oleh tanaman. Luas daun semakin besar maka semakin banyak sinar matahari yang dapat diserap oleh daun sehingga proses fotosintesis akan meningkat (Barclay, 1998). 
Tabel 2. Pengaruh Tumpangsari Jagung dan Kedelai terhadap Tinggi Tanaman Jagung pada 4 MST, 6 MST, dan 8 MST.

\begin{tabular}{|c|c|c|c|}
\hline \multirow[t]{2}{*}{ Perlakuan } & \multicolumn{3}{|c|}{ Tinggi (cm) } \\
\hline & $4 \mathrm{MST}$ & $6 \mathrm{MST}$ & $8 \mathrm{MST}$ \\
\hline $\mathrm{A}$ & $97,63 \mathrm{a}$ & $184,38 \mathrm{a}$ & $247,75 \mathrm{a}$ \\
\hline B & 85,07 a & $143,00 \mathrm{a}$ & $193,75 a$ \\
\hline $\mathrm{C}$ & $103,75 \mathrm{a}$ & $192,50 \mathrm{a}$ & $234,88 \mathrm{a}$ \\
\hline $\mathrm{D}$ & $99,25 \mathrm{a}$ & 192,13 a & $259,00 \mathrm{a}$ \\
\hline $\mathrm{E}$ & $98,88 \mathrm{a}$ & $178,13 \mathrm{a}$ & $217,13 \mathrm{a}$ \\
\hline $\mathrm{F}$ & 77,13 a & 138,00 a & $170,63 \mathrm{a}$ \\
\hline G & 83,69 a & $164,13 \mathrm{a}$ & $216,88 \mathrm{a}$ \\
\hline $\mathrm{H}$ & 93,38 a & $165,25 \mathrm{a}$ & $212,50 \mathrm{a}$ \\
\hline I & $93,25 \mathrm{a}$ & $159,75 \mathrm{a}$ & $211,25 \mathrm{a}$ \\
\hline $\mathrm{J}$ & 88,13 a & 148,63 a & $192,50 \mathrm{a}$ \\
\hline $\mathrm{K}$ & 109,63 a & 178,75 a & $216,38 \mathrm{a}$ \\
\hline $\mathrm{L}$ & $67,25 \mathrm{a}$ & $136,75 \mathrm{a}$ & $193,63 \mathrm{a}$ \\
\hline M & $95,69 a$ & $170,38 \mathrm{a}$ & $222,50 \mathrm{a}$ \\
\hline $\mathrm{N}$ & $96,07 \mathrm{a}$ & $162,25 \mathrm{a}$ & $228,13 \mathrm{a}$ \\
\hline $\mathrm{O}$ & $92,07 \mathrm{a}$ & $176,13 \mathrm{a}$ & $213,75 a$ \\
\hline $\mathrm{P}$ & $98,00 \mathrm{a}$ & $164,25 \mathrm{a}$ & $221,50 \mathrm{a}$ \\
\hline Q & $89,82 \mathrm{a}$ & $163,25 \mathrm{a}$ & $202,00 \mathrm{a}$ \\
\hline$\widehat{\mathrm{R}}$ & $93,82 \mathrm{a}$ & $156,88 \mathrm{a}$ & $222,50 \mathrm{a}$ \\
\hline$S$ & $94,13 \mathrm{a}$ & 170,25 a & $235,63 a$ \\
\hline $\mathrm{T}$ & $91,94 \mathrm{a}$ & 154,88 a & $213,13 \mathrm{a}$ \\
\hline
\end{tabular}

Keterangan : Nilai rata-rata yang diikuti huruf yang sama pada kolom yang sama tidak berbeda nyata menurut Uji Skott Knott pada taraf 5\%.

Tabel 3. Pengaruh Tumpangsari Jagung dan Kedelai terhadap Indeks Luas Daun Tanaman Jagung.

\begin{tabular}{cc}
\hline Perlakuan & ILD \\
\hline A & $7,03 \mathrm{a}$ \\
B & $6,52 \mathrm{a}$ \\
C & $6,00 \mathrm{a}$ \\
D & $6,69 \mathrm{a}$ \\
E & $6,90 \mathrm{a}$ \\
F & $5,69 \mathrm{a}$ \\
G & $6,48 \mathrm{a}$ \\
H & $5,90 \mathrm{a}$ \\
I & $6,87 \mathrm{a}$ \\
J & $6,82 \mathrm{a}$ \\
K & $6,84 \mathrm{a}$ \\
L & $5,58 \mathrm{a}$ \\
M & $6,35 \mathrm{a}$ \\
N & $5,94 \mathrm{a}$ \\
O & $6,16 \mathrm{a}$ \\
P & $6,39 \mathrm{a}$ \\
Q & $6,13 \mathrm{a}$ \\
R & $5,85 \mathrm{a}$ \\
S & $6,25 \mathrm{a}$ \\
T & $6,07 \mathrm{a}$ \\
\hline
\end{tabular}

Keterangan : Nilai rata-rata yang diikuti huruf yang sama pada kolom yang sama tidak berbeda nyata menurut Uji Gugus Skott Knott pada taraf 5\%.
ILD tanaman jagung dewasa berkisar antara 3,5 sampai 8,5 (Loomis et al., 1968). ILD tanaman jagung pada percobaan berkisar dari 5,58 hingga 7,03. Hal ini didukung oleh Edy et all, (2011), ILD jagung yang ditumpangsarikan dengan kacang hijau, lebih besar dibandingkan dengan jagung yang ditanam secara monokultur. ILD tanaman jagung dewasa berkisar antara 3,5 sampai 8,5 (Loomis et al., 1968). ILD tanaman jagung pada percobaan berkisar dari 5,58 hingga 7,03. Hal ini dimungkinkan karena faktor lain yang dapat mempengaruhi besarnya ILD antara lain adalah jarak tanam dan penyediaan unsur hara nitrogen. Nitrogen merupakan salah satu unsur hara makro essensial bagi tanaman yang diperlukan dalam pembentukan dan pertumbuhan vegetatif tanaman dan sebagai bahan dasar penyusun protein serta pembentukan klorofil (Goldsworthy dan Fischer, 1992).

Panjang dan Diameter Tongkol Jagung. Berdasarkan Tabel 4, Tumpangsari jagung dan kedelai menunjukkan berbeda tidak nyata terhadap panjang tongkol jagung sedangkan terhadap diameter tongkol berbeda nyata dibandingkan dengan kontrol. Pada percobaan ini, panjang tongkol berkisar antara 11,62 cm hingga 19,20 cm.

Tabel 4. Pengaruh Tumpangsari Jagung dan Kedelai terhadap Panjang dan Diamater Tongkol Jagung.

\begin{tabular}{ccc}
\hline Perlakuan & $\begin{array}{c}\text { Panjang } \\
\text { Tongkol }(\mathbf{c m})\end{array}$ & $\begin{array}{c}\text { Diameter } \\
\text { Tongkol }(\mathbf{c m})\end{array}$ \\
\hline A & $17,88 \mathrm{a}$ & $4,70 \mathrm{a}$ \\
B & $16,02 \mathrm{a}$ & $3,97 \mathrm{c}$ \\
C & $16,67 \mathrm{a}$ & $4,78 \mathrm{a}$ \\
D & $16,23 \mathrm{a}$ & $4,40 \mathrm{~b}$ \\
E & $16,72 \mathrm{a}$ & $4,36 \mathrm{~b}$ \\
F & $17,42 \mathrm{a}$ & $3,78 \mathrm{c}$ \\
G & $16,37 \mathrm{a}$ & $4,71 \mathrm{a}$ \\
H & $16,97 \mathrm{a}$ & $4,78 \mathrm{a}$ \\
I & $18,22 \mathrm{a}$ & $4,67 \mathrm{a}$ \\
J & $15,58 \mathrm{a}$ & $4,44 \mathrm{~b}$ \\
K & $19,20 \mathrm{a}$ & $5,06 \mathrm{a}$ \\
$\mathrm{L}$ & $16,25 \mathrm{a}$ & $4,30 \mathrm{~b}$ \\
M & $15,55 \mathrm{a}$ & $4,63 \mathrm{a}$ \\
N & $14,67 \mathrm{a}$ & $4,28 \mathrm{~b}$ \\
O & $15,62 \mathrm{a}$ & $4,69 \mathrm{a}$ \\
P & $11,62 \mathrm{a}$ & $4,33 \mathrm{~b}$ \\
Q & $14,99 \mathrm{a}$ & $4,59 \mathrm{a}$ \\
R & $15,12 \mathrm{a}$ & $4,36 \mathrm{~b}$ \\
S & $15,73 \mathrm{a}$ & $5,06 \mathrm{a}$ \\
T & $17,27 \mathrm{a}$ & $4,80 \mathrm{a}$ \\
\hline
\end{tabular}

Keterangan : Nilai rata-rata yang diikuti huruf yang sama pada kolom yang sama tidak berbeda nyata menurut Uji Gugus Skott Knott pada taraf 5\%. 
Diameter terbesar terdapat pada perlakuan A, C, G, H, I, K, M, O, Q, S dan T. Hal ini diduga karena tanaman kedelai yang dapat menambat $\mathrm{N}$ dari udara dan kondisi tanah dengan nilai kandungan $\mathrm{N}$ sebesar $0,21 \%$ yang mendukung ketersediaan $\mathrm{N}$ dalam tanah, didukung oleh Tarigan (2007) bahwa nitrogen berpengaruhi terhadap diameter tongkol. Nitrogen merupakan komponen utama dalam proses sintesa protein yang berkolerasi positif panjang dan diameter tongkol. Selain itu, faktor genetik berpengaruh terhadap panjang dan diameter tongkol.

Jumlah Biji Per Tongkol. Jumlah biji terbanyak terbanyak terdapat pada perlakuan A, C, H, I, K, L, M, O, Q, Hal ini diduga karena tiap tanaman memiliki faktor genetik yang berbedabeda. Perkembangan biji dipengaruhi oleh faktor-faktor seperti varietas tanaman, ketersediaan unsur hara dan lingkungan seperti cahaya matahari dan kelembaban udara (Jumin, 2005).

Tabel 5. Pengaruh Tumpangsari Jagung dan Kedelai terhadap Jumlah Biji Jagung Per Tongkol.

\begin{tabular}{cc}
\hline Perlakuan & $\begin{array}{c}\text { Jumlah Biji Per Tongkol } \\
\text { (butir) }\end{array}$ \\
\hline A & $484,25 \mathrm{a}$ \\
B & $395,88 \mathrm{c}$ \\
C & $527,88 \mathrm{a}$ \\
D & $453,88 \mathrm{~b}$ \\
E & $455,50 \mathrm{~b}$ \\
F & $462,00 \mathrm{~b}$ \\
G & $466,25 \mathrm{~b}$ \\
H & $501,13 \mathrm{a}$ \\
I & $499,25 \mathrm{a}$ \\
J & $461,50 \mathrm{~b}$ \\
K & $493,25 \mathrm{a}$ \\
L & $531,63 \mathrm{a}$ \\
M & $513,63 \mathrm{a}$ \\
N & $406,00 \mathrm{c}$ \\
O & $505,88 \mathrm{a}$ \\
P & $341,00 \mathrm{c}$ \\
Q & $549,88 \mathrm{a}$ \\
R & $517,25 \mathrm{a}$ \\
S & $562,13 \mathrm{a}$ \\
T & $596,00 \mathrm{a}$ \\
\hline
\end{tabular}

Keterangan : Nilai rata-rata yang diikuti huruf yang sama pada kolom yang sama tidak berbeda nyata menurut Uji Gugus Skott Knott pada taraf 5\%.

Bobot Biji Pipilan Kering per Tanaman dan per Petak. Berdasarkan Tabel 6 menunjukkan bahwa tumpangsari jagung dan kedelai berbeda nyata terhadap bobot biji pipilan kering pertanaman dan bobot biji pipilan kering per petak dibandingkan dengan kontrol.
Tabel 6. Pengaruh Tumpangsari Jagung dan Kedelai terhadap Bobot Biji Pipilan Kering Jagung per Tanaman.

\begin{tabular}{|c|c|c|c|}
\hline Perlakuan & $\begin{array}{l}\text { Bobot Biji } \\
\text { Pipilan } \\
\text { Kering per } \\
\text { Tanaman } \\
\text { (g) }\end{array}$ & $\begin{array}{l}\text { Bobot Biji } \\
\text { Pipilan } \\
\text { Kering per } \\
\text { petak (kg) }\end{array}$ & $\begin{array}{c}\text { Potensi } \\
\text { Bobot Biji } \\
\text { Pipilan } \\
\text { Kering per } \\
\text { ha (ton) } \\
\end{array}$ \\
\hline $\mathrm{A}$ & $140,66 \mathrm{~b}$ & $2,12 \mathrm{~b}$ & 4,70 \\
\hline B & 105,32 c & $1,67 \mathrm{~b}$ & 3,70 \\
\hline $\mathrm{C}$ & $142,68 \mathrm{~b}$ & $2,86 \mathrm{a}$ & 6,35 \\
\hline $\mathrm{D}$ & $122,25 \mathrm{~b}$ & $3,42 \mathrm{a}$ & 7,61 \\
\hline $\mathrm{E}$ & $137,70 \mathrm{~b}$ & $2,44 \mathrm{~b}$ & 5,42 \\
\hline $\mathrm{F}$ & 93,77 c & $1,01 \mathrm{~b}$ & 2,25 \\
\hline G & $137,49 \mathrm{~b}$ & $2,10 \mathrm{~b}$ & 4,66 \\
\hline $\mathrm{H}$ & $134,07 \mathrm{~b}$ & $2,23 \mathrm{~b}$ & 4,97 \\
\hline I & $138,24 \mathrm{~b}$ & $2,06 \mathrm{~b}$ & 4,57 \\
\hline $\mathrm{J}$ & $145,41 \mathrm{~b}$ & $1,43 \mathrm{~b}$ & 3,19 \\
\hline K & 181,14 a & $3,66 \mathrm{a}$ & 8,13 \\
\hline $\mathrm{L}$ & $134,74 \mathrm{~b}$ & $2,46 \mathrm{~b}$ & 5,47 \\
\hline M & $94,63 \mathrm{c}$ & $1,56 \mathrm{~b}$ & 3,48 \\
\hline $\mathrm{N}$ & $71,09 \mathrm{~d}$ & $1,81 \mathrm{~b}$ & 4,02 \\
\hline $\mathrm{O}$ & $148,83 \mathrm{~b}$ & $2,02 \mathrm{~b}$ & 4,49 \\
\hline $\mathrm{P}$ & $68,98 \mathrm{~d}$ & $1,42 \mathrm{~b}$ & 3,15 \\
\hline $\mathrm{Q}$ & $159,58 \mathrm{~b}$ & $2,60 \mathrm{a}$ & 5,77 \\
\hline $\mathrm{R}$ & $130,64 b$ & $2,25 \mathrm{~b}$ & 5,00 \\
\hline$S$ & 192,58 a & $3,30 \mathrm{a}$ & 7,34 \\
\hline $\mathrm{T}$ & $184,52 \mathrm{a}$ & $3,04 \mathrm{a}$ & 6,75 \\
\hline
\end{tabular}

Keterangan : Nilai rata-rata yang diikuti huruf yang sama pada kolom yang sama tidak berbeda nyata menurut Uji Gugus Skott Knott pada taraf 5\%.

Perlakuan K, S dan $\mathrm{T}$ menghasilkan bobot biji pipilan kering pertanaman tertinggi $(181,41 \mathrm{~g}$, $192,58 \mathrm{~g}, 184,52 \mathrm{~g}$ ) dibandingkan dengan yang lainnya dan terendah pada perlakuan $\mathrm{N}$ dan $\mathrm{P}$ $(71,09 \mathrm{~g}$ dan $68,98 \mathrm{~g})$. Hal ini diduga karena terjadi persaingan pengambilann unsur hara, air dan cahaya yang berbeda antara genotip tanaman jagung dengan tanaman kedelai. Perbedaan faktor genetik dapat memperlihatkan fenotik yang beragam. Dengan demikian genotip jagung yang menghasilkan hasil yang tinggi kemungkinan merupakan genotip toleran yang tumbuh optimal pada kondisi lingkungan percobaan ini

Jagung berkompetisi dengan kedelai, menurunkan berat biji untuk menyeimbangkan hilangnya biomassa pada fase vegetatif (Carruthers et al., 2000). Besaran indeks panen jagung pada tumpangsari genotip jagung hibrida dengan kedelai sebesar 0,29 hingga 0,55. Indeks panen merupakan rasio hasil bobot kering biji dengan hasil bobot kering total tanaman. Nilai indeks panen optimal dapat bervariasi dari 0,15 hingga 0,52 (Goldsworthy 
and Fisher, 1992). Menurut Sarjoni (2013), indeks panen tanaman jagung yang lebih rendah diduga akibat pembagian hasil bahan kering total lebih banyak ke batang dan daun jagung dibandingkan ke biji. Indeks panen dianggap sebagai ukuran keberhasilan biologis tanaman dalam asimilasi fotosintat dan pembentukan komponen hasil (Fitter dan Hay, 1991).

Tabel 7. Pengaruh Tumpangsari Jagung dan Kedelai terhadap Indeks Panen Jagung.

\begin{tabular}{cc}
\hline Perlakuan & Indeks Panen \\
\hline A & $0,48 \mathrm{a}$ \\
B & $0,44 \mathrm{a}$ \\
C & $0,47 \mathrm{a}$ \\
D & $0,44 \mathrm{a}$ \\
E & $0,50 \mathrm{a}$ \\
F & $0,42 \mathrm{a}$ \\
G & $0,45 \mathrm{a}$ \\
H & $0,45 \mathrm{a}$ \\
I & $0,46 \mathrm{a}$ \\
J & $0,41 \mathrm{a}$ \\
K & $0,44 \mathrm{a}$ \\
L & $0,42 \mathrm{a}$ \\
M & $0,42 \mathrm{a}$ \\
N & $0,37 \mathrm{a}$ \\
O & $0,48 \mathrm{a}$ \\
P & $0,29 \mathrm{a}$ \\
Q & $0,50 \mathrm{a}$ \\
R & $0,43 \mathrm{a}$ \\
S & $0,55 \mathrm{a}$ \\
T & $0,48 \mathrm{a}$ \\
\hline
\end{tabular}

Keterangan : Nilai rata-rata yang diikuti huruf yang sama pada kolom yang sama tidak berbeda nyata menurut Uji Gugus Skott Knott pada taraf 5\%.

\section{Evaluasi Tumpangsari}

Nisbah Kesetaraan Lahan (NKL). Tabel 8 menunjukkan bahwa tumpangsari jagung dan kedelai memberikan nilai Nisbah Kesetaraan Lahan (NKL) terbesarterdapat pada perlakuan Q (genotip F1I x G203-1 + kedelai) sebesar 1,45, artinya total produktivitas dalam sistem tumpangsari ini memperoleh keuntungan $45 \%$ dibandingkan sistem tanam tunggal jagung dengan demikian pada perlakuan $Q$ untuk menghasilkan hasil pipilan kering jagung 5,77 ton ha $^{-1}$ (Tabel 6) dan kedelai 0,27 / 0.28ton ha-1 pada pertanaman tunggal kedelai, diperlukan lahan 1,45 ha pada penanaman tunggal kedelai. Hal ini menujukkan bahwa tumpangsari jagung hibrida dan kedelai lebih menguntungkan dibandingkan dengan pertanaman tunggal yang memberikan efisiensi dalam pemanfaatan lahan.

NKL terendah ada pada perlakuan $\mathrm{F}$ (genotip F1C x G203-1 + kedelai) sebesar 0,68. Hal ini mengindikasikan bahwa sistem tum- pangsari $\mathrm{F}$-hanya mencapai $68 \%$ dari hasil pertanaman tunggal kedelai. Hal ini sejalan dengan pernyataan Yuwariah (2011) bahwa perlakuan NKL kurang dari 1, tidak menguntungkan untuk pertanaman tumpangsari. Selain itu, faktor terpenting yang mempengaruhi NKL dari tumpangsari jagung dengan kedelai adalah cahaya. NKL rendah terjadi ketika kacangkacangan sangat ternaungi oleh jagung sehingga merugikan untuk kacang-kacangan (Amanullah et al., 2012). Jagung hibrida pada perlakuan C, D, E, G, I, J, K, L, P, Q, S dan T cocok digunakan dalam pola tanam tumpangsari karena memiliki NKL lebih dari 1.

Tabel 8. Hasil Nilai Kesetaraan Lahan.

\begin{tabular}{cccccc}
\hline Perlakuan & $\begin{array}{c}\text { Tunggal } \\
\text { Kedelai } \\
\text { (ton/ha) }\end{array}$ & $\begin{array}{c}\text { Tumpang- } \\
\text { sari } \\
\text { kedelai } \\
\text { ton/ha) }\end{array}$ & $\begin{array}{c}\text { Tunggal } \\
\text { Jagung } \\
\text { (ton/ha) }\end{array}$ & $\begin{array}{c}\text { Tumpang- } \\
\text { sari } \\
\text { Jagung } \\
\text { (ton/ha) }\end{array}$ & \\
\hline A & 1,13 & 0,25 & 8,60 & 4,70 & 0,77 \\
B & 1,13 & 0,24 & 5,85 & 3,70 & 0,85 \\
C & 1,13 & 0,23 & 5,81 & 6,35 & 1,29 \\
D & 1,13 & 0,35 & 9,16 & 7,61 & 1,14 \\
E & 1,13 & 0,33 & 5,98 & 5,42 & 1,20 \\
F & 1,13 & 0,34 & 6,00 & 2,25 & 0,68 \\
G & 1,13 & 0,30 & 8,58 & 4,66 & 0,81 \\
H & 1,13 & 0,30 & 7,27 & 4,97 & 0,95 \\
I & 1,13 & 0,27 & 6,02 & 4,57 & 1,00 \\
J & 1,13 & 0,30 & 3,18 & 3,19 & 1,27 \\
K & 1,13 & 0,31 & 10,49 & 8,13 & 1,05 \\
L & 1,13 & 0,25 & 4,73 & 5,47 & 1,38 \\
M & 1,13 & 0,29 & 7,93 & 3,48 & 0,69 \\
N & 1,13 & 0,24 & 5,12 & 4,02 & 1,00 \\
O & 1,13 & 0,30 & 8,29 & 4,49 & 0,81 \\
P & 1,13 & 0,28 & 3,64 & 3,15 & 1,11 \\
Q & 1,13 & 0,28 & 4,80 & 5,77 & 1,45 \\
R & 1,13 & 0,27 & 10,96 & 5,00 & 0,70 \\
S & 1,13 & 0,28 & 7,92 & 7,34 & 1,17 \\
T & 1,13 & 0,30 & 7,60 & 6,75 & 1,15 \\
\hline & & & & &
\end{tabular}

Rasio Kompetisi (RK). Berdasarkan Tabel 9. Tumpangsari jagung dan kedelai berpengaruh terhadap rasio kompetisi jagung dan kedelai (RK). RK kedelai pada semua perlakuan lebih rendah dibandingkan RK jagung. Hal ini menunjukkan bahwa jagung lebih kuat berkom-petisi dibandingkan kedelai karena terjadi persaingan cahaya matahari karena jagung lebih tinggi dan tajuk lebih lebar. Dengan demikian tanaman jagung lebih unggul persaingannya dalam menyerap air, unsur hara, cahaya dan pertumbuhan akar, dibanding kedelai tersebut menyebabkan sehingga pertumbuhan kedelai terhambat. Rasio kompetisi adalah alat ukur untuk melihat kompetisi secara kuantitatif dari tanaman yang ditumpangsarikan (Yuwariah (2011). 
Tabel 9. Rasio Kompetisi.

\begin{tabular}{ccc}
\hline Perlakuan & RK Jagung & RK Kedelai \\
\hline A & 2.45 & 0,30 \\
B & 2.97 & 0,19 \\
C & 5.49 & 0,19 \\
D & 2.67 & 0,33 \\
E & 3.11 & 0,26 \\
F & 1.24 & 0,46 \\
G & 2.02 & 0,29 \\
H & 2.54 & 0,38 \\
I & 3.13 & 0,26 \\
J & 3.82 & 0,27 \\
K & 2.85 & 0,31 \\
L & 5.20 & 0,22 \\
M & 1.71 & 0,38 \\
N & 3.70 & 0,28 \\
O & 2.02 & 0,37 \\
P & 3.56 & 0,24 \\
Q & 4.83 & 0,21 \\
R & 1.90 & 0,34 \\
S & 3.77 & 0,22 \\
T & 3.35 & 0,28 \\
\hline
\end{tabular}

Semua perlakuan menunjukkan kompetisi rasio jagung lebih besar dibandingkan kedelai. Hal ini sejalan dengan penyataan Ariel et al., (2013) yang menyatakan pertumbuhan serealia meningkat akan mengakibatkan pertumbuhan kacang-kacangan tertekan. Penelitian Muoneke et al., (2007) menyatakan bahwa terjadi kompetisi interspesifik seperti air, cahaya, udara dan nutrisi selain itu tanaman jagung $\left(\mathrm{C}_{4}\right)$ lebih agresif dibandingkan tanaman kedelai $\left(C_{3}\right)$. menunjukkan nilai kompetisi rasio jagung yang ditumpangsarikan dengan kacang tanah sebesar 1,98 vs 0,51( Charani et al., (2015). Alla et al., (2014), menunjukkan bahwa tanaman jagung lebih dominan dan lebih kompetitif dibandingkan dengan kacang tunggak dengan nilai rasio kompetisi sebesar 1,89 vs 0,52 .

\section{Kesimpulan dan Saran}

1. Tumpangsari genotip jagung hibrida berpengaruh terhadap pertumbuhan dan hasil jagung hibrida dan evaluasi tumpangsari jagung dan kedelai.

2. Tumpangsari jagung hibrida genotip C, D, K, $\mathrm{Q}, \mathrm{S}, \mathrm{T}$ dan kedelai menghasilkan hasil pipilan kering perpetak yang tertinggi, masing-masing $2,86 \mathrm{~kg}$ petak $^{-1}\left(6,35\right.$ ton ha $\left.^{-1}\right)$.
3. Tumpangsari jagung hibrida semua genotip dan kedelai menunjukkan nilai Evaluasi tumpangsari sebesar $45 \%$.

Saran. Perlu penelitian yang sama pada musim tanam yang berbeda, dan varietas kedelai yang berbeda.

\section{Ucapan Terima Kasih}

1. Fakultas Pertanian Universitas Padjadjaran.

2. Mahasiswa Peminatan Pangan Departemen Budidaya Pertanian Fakultas Pertanian Universitas Padjadjaran.

\section{Daftar Pustaka}

Aldillah, R. 2015. Proyeksi produksi dan konsumsi kedelai indonesia. J. Ekon. Kuantitatif Terap. 8(1): 9 - 23.

Alla, W.A.H., E.M. Shalaby, R.A. Dawood, and A.A. Zohry. 2014. Effect of cowpea ( Vigna sinensis L .) with maize (Zea mays L.) intercropping on yield and its components. International Scholarly and Scientific Research \& Innovation. 8(11): 1258-1264.

Amanullah, Khan, F., Muhammad, H., Jan, A. U., \& Ali, G. 2016. Land equivalent ratio , growth, yield and yield components response of mono-cropped vs intercropped common bean and maize with and without compost application. Agric. Biol. J. N. Am. 7(2): 40-49.

Ariel, C. E., Eduardo, O. A., Benito, G. E., \& Lidia, G. 2013. Effects of two plant arrangements in corn (Zea mays L .) and soybean (Glycine max L. Merrill) intercropping on soil nitrogen and phosphorus status and growth of component crops at an Argentinean Argiudoll. American J. of Agriculture and Forestry. 1(2): 22-31.

Barclay, H.J. 1998. Conversion of total leaf area to projected leaf area in lodgepole pine and Douglas-fir. Tree Physiol. 18: 185-194.

Beets, W.C. 1982. Multiple Cropping and Tropical Farming Systems. England: Westview Press

Belel, M.D., R. a. Halim, M.Y. Rafii, and H.M. Saud. 2014. Intercropping of corn with some selected legumes for improved forage production: A Review. J. Agric. Sci. 6(3): 48-62 
Carruthers, K., Prithiviraj, B., Fe, Q., Cloutier, D., Martin, R. C., \& Smith, D. L. 2000. Intercropping corn with soybean, lupin and forages: yield component responses. European Journal of Agronomy. 12(2): 103-115.

Charani E., Sharifi P., Aminpanah H. 2015. Evaluation of grain yield component in intercropping of maize and bean. Biharean Biologist (online first): art.151413

Edy, Tohari, D. Indradewa, dan D. Shiddieq. 2011. Jurnal Agrotropika 16 ( 1 ): 38-44, Januari - Juni 2011. 16(November 2010): 3844.

Fitter, A.H. dan R.K.M. Hay. 1991. Fisiologi Lingkungan Tanaman. Gadjah Mada University Press. Yogyakarta. 421 p.

Gardner, F.P., R.B. Pearce, dan R.L. Mitchell. 1991. Physiology of Crop Plants (Fisiologi Tanaman Budidaya, alih bahasa oleh Susilo, H.). Universitas Indonesia Press. Jakarta. 428 p.

Gerpacio, R.V., dan P.L. Pingali. 2007. Tropical and Subtropical Maize in Asia: Production Systems, Constraints, and Research Priorities. Mexico, D.F.: CIMMYT.

Goldsworthy, P. R dan RL. Fisher. 1992. Fisiologi Tanaman Budidaya. Diterjemahkan oleh Tohari. Universitas Indonesia Press. Jakarta

Jumin, Hasan Basri. 2005. Dasar - Dasar Agronomi. PT. Raja Grafindo Persada. Edisi Revisi. Jakarta.

KEMENPERIN.2016. RI Impor Jagung 2,4 Juta Ton. Tersedia online di http:/ / kemenperin. go.id/artikel/13892/2016,-RI-ImporJagung-2,4-Juta-Ton Diakses pada 30 Maret 2016.

Litbang. 2015. Target National Produksi Kedelai 2016 Meningkat. Tersedia online di http:/ / www.litbang.pertanian.go.id/berita /one/2468/ (diakses pada 2 Mei 2016)

Loomis, R.S., Williams, W. A., Duncan,W.G., Dovrat,A. and Nunez,A. F. 1968. Quantitative description of foliage display and light absoption in field communities of corn plants. CropScie. 8(3):352-356

Lv, Y., C. Francis, P. Wu, X. Chen, and X. Zhao. 2014. Maize-soybean intercropping interactions above and below ground. Crop Sci. 54(3): 914-922

Muoneke CO, Ogwuche MAO, Kalu BA .2007.Effect of maize planting density on the performance of maize/soybean intercropping system in a Guinea savannah agro-ecosystem. African J. of Agricultural Research.2(12): 667-677

Pusat Data dan Sistem Informasi Pertanian.2015. Outlook Komoditas Pertanian Tanaman Pangan Kedelai.

Salvagiotti, F., K.G. Cassman, J.E. Specht, D.T. Walters, and A. Weiss. 2008. Nitrogen uptake, fixation and response to fertilizer $\mathrm{N}$ in soybeans: A review.

Sarjoni. 2013. Pengaruh bahan organik dan waktu tanam pada hasil tumpangsari jagung dan kacang tanah. Widyariset 16(30): 457-466.

Suarni, and M. Yasin. 2011. Jagung sebagai sumber pangan fungsional. Iptek Tanam. Pangan 6(1): 41-56.

Sumarno. 2011. Perkembangan Teknologi Budi Daya Kedelai di Lahan Sawah. Iptek Tanam. Pangan 6(2): 139-151.

Syafii, M., I. Cartika, dan D. Ruswandi. 2015. Multivariate analysis of genetic diversity among some maize genotypes under maize-albizia cropping system in Indonesia. Asian J. Crop Sci. 7(4): 244-255

Tarigan, Ferry H. 2007. Pengaruh pemberian pupuk organik green giant dan pupuk daun super bionik terhadap pertumbuhan dan produksi tanaman jagung ( Zea mays L.). Jurnal Agrivigor 23 (7): 78-85.

Yuwariah, Y. 2011. Peran Tanam Sela dan Tumpangsari Bersisipan Berbasis Padi Gogo Toleran Naungan. Giratuna. Bandung 